\title{
MENINGKATKAN KREATIVITAS SENI RUPA MELALUI KEGIATAN PRAKARYA DENGAN MEDIA BAHAN LIMBAH ANORGANIK PADA ANAK KELOMPOK B1 PAUD ISLAM INTAN INSANI KOTA BENGKULU
}

\author{
Nur Aprita \\ moodyayunda@gmail.com \\ Sri Saparahayuningsih \\ srisaparahayu@yahoo.co.id \\ Wembrayarli. \\ Wembrayarli@yahoo.com
}

\begin{abstract}
Permasalahan pada penelitian ini yaitu bagaimana kegiatan prakarya dengan media bahan limbah anorganik dapat meningkatkan kreativitas seni rupa anak. Tujuan penelitian ini adalah untuk memperoleh gambaran mengenai peningkatan kreativitas seni rupa anak setelah diterapkannya kegiatan prakarya dengan media bahan limah anorganik. Subjek dalam penelitian ini yaitu anak di kelompok B1 Paud Islam Intan Insani Kota Bengkulu yang berjumlah 18 anak, terdiri dari 12 orang anak laki-laki dan 6 orang anak perempuan. Metode penelitian ini menggunakan penelitian tindakan kelas. Teknik pengumpulan data menggunkan teknik observasi. Data dianalisis dengan menggunakan uji rata-rata dan rumus ketuntasan belajar. Hasil penelitian menunjukkan kreativitas seni rupa anak dapat ditingkatkan melalui kegiatan prakarya dengan media bahan limbah anorganik. Dari hasil penelitian ini direkomendasikan kepada guru PAUD dalam meningkatkan kreativitas seni rupa anak dapat menggunakan kegiatan prakarya dengan media bahan limbah anorganik. Bagi peneliti selanjutnya diharapkan penelitian tentang kreativitas seni rupa anak menggunakan kegiatan prakarya dengan media lainnya seperti bahan alam.
\end{abstract}

Keywords: Kreativitas Seni Rupa, Kegiatan Prakarya, Media Bahan Limbah Anorganik.

\section{PENDAHULUAN}

Kreativitas seni rupa menurut Renzulli
dalam Munandar (2000:25) sebagai
kemampuan umum untuk menciptakan
sesuatu yang baru, sebagai kemampuan
untuk memberikan gagasan-gagasan baru, yang dapat diterapkan dalam pemecahan masalah, atau sebagai kemampuan untuk melihat hubungan-hubungan baru antara unsur-unsur yang sudah ada sebelumnya. Rhodes dalam Munandar (1988; 1-5) menjelaskan bahwa pengembangan kreativitas pada diri seseorang dapat dilakukan melalui pendekatan $4 \mathrm{P}$, yaitu Person (pribadi), di mana tindakan kreatif muncul dari keunikan keseluruhan kepribadian dalam interaksi dengan lingkungan; Process (proses), di mana langkah-langkah proses kreatif dimulai dari tahap persiapan, inkubasi, iluminasi, dan verifikasi; Press (dorongan), berupa dorongan internal dan eksternal dari lingkungan dan psikologis; dan Product (hasil akhir) yang ditandai dengan orisinalitas, kebaruan, kebermaknaan, dan teramati (observable). Masalahnya adalah anak belum menuangkan idenya dalam menghasilkan suatu produk kreatif. Prakarya memiliki pengertian keterampilan, hastakarya, kerajinan tangan, atau 
keterampilan tangan. Prakarya mempunyai peranan penting dalam pengembangan kreativitas dan mengembangkan menjadi sebuah inovasi baru (blog.bersiap.com/informasi/pengertianprakarya-dan-kewirausahaan-terlengkap). Pembelajaran mengenai kreativitas seni rupa anak melalui membuat prakarya belum diterapkan dengan maksimal, sehingga tingkat kreativitas seni rupa anak masih rendah. Pemanfaatan bahan limbah anorganik bagi usia dini merupakan kegiatan bermain dan memiliki unsur pendidikan yang kompleks, disamping harganya yang murah dan menarik bagi anak, juga bahannya banyak dan mudah diperoleh disekitar lingkungan anak, maka dipandang perlu untuk melakukan upayaupaya perbaikan dalam program pelaksanaan kegiatan pengembangan potensi anak. Upaya tersebut, dilakukan sebagai bentuk tanggung jawab kongkrit dan kewajiban untuk mengoptimalkan kreativitas seni rupa yang dimiliki anak (http://harto1234kambaton.blogspot.co.id 2013/06). Guru belum maksimal dalam memanfaatkan lingkungan sebagai inspirasi dalam melaksanakan kegiatan pembelajaran, padahal secara tidak langsung dengan memanfaatkan bahan limbah anorganik yang ada disekitar kita seperti botol plastic bekas, dapat melalui pemanfaatan bahan limbah anorganik dalam meningkatkan kreativitas seni rupa anak. Adapun rumusan masalah dalam penelitian ini adalah :

1. Bagaimana penerapan kegiatan prakarya melalui pemanfaatan bahan limbah anorganik dalam meningkatkan kreativitas seni rupa anak?

2. Apakah kreativitas seni rupa anak dapat ditingkatkan melalui penerapan kegiatan prakarya menggunakan pemanfaatan bahan limbah anorganik pada anak kelompok B1 PAUD Islam Intan Insani Kota Bengkulu?

\section{METODE}

Penelitian ini menggunakan jenis Penelitian Tindakan Kelas (PTK). Penelitian tindakan kelas adalah upaya pemecahan masalah dengan menggunakan cara-cara tertentu disertai pengamatan yang cermat untuk meningkatkan proses dan hasil yang dicapai (Aqib,2008:15).

Penelitian tindakan kelas ini dilakukan di PAUD Sambela Kota Bengkulu, dengan subjek penelitian yaitu anak kelompok B yang berjumlah 18 orang terdiri dari 12 orang anak laki-laki dan 6 orang anak perempuan. Penelitian tindakan kelas ini dilakukan dengan menggunakan kegiatan prakarya untuk meningkatkan kreativitas seni rupa. Penelitian ini dilaksanakan dalam II siklus masing-masing siklus dilakuakn sebanyak 3 kali pertemuan, setiap satu kali pertemuan dilakukan observasi untuk mengetahui peningkatan kemampuan membaca permulaan anak. Penelitian ini dilaksanakan selama 2 minggu dari tanggal Agustus 2017 dengan tahap perencanaan, pelaksanaan, pengamatan (observasi) dan refleksi. Morrison (2012:165) menyatakan bahwa observasi dirancang untuk mengumpulkan informasi sebagai bahan refleksi yang bertujuan untuk meningkatkan dan memandu pengajaran dan untuk membantu memastikan semua anak belajar.

Indikator keberhasilan pada penelitian ini yaitu jika anak mencapai ketuntasan mencapai 75\%.

\section{HASIL DAN PEMBAHASAN \\ Hasil}

Berdasarkan hasil penelitian yang dilakukan Selama dua minggu dalam 2 siklus secara umum telah mengalami peningkatan pada kreativitas seni rupa anak melalui kegiatan prakarya dengan media bahan limbah anorganik yaitu di siklus I 
keseluruhan ketuntasan belajar anak mendapat presentase $64 \%$, sedangkan pada siklus II secara keseluruhan ketuntasan belajar anak mengalami peningkatan menjadi $84 \%$. Dari tiga aspek kretivitas seni rupa anak yang dinilai yaitu Orisinalitas di siklus I dengan nilai rata-rata 56\% kemudian di siklus II meningkat menjadi 90\%. Pada aspek resolution di siklus I mendapat nilai rata-rata $62 \%$ di siklus II meningkat menjadi 84\% Pada aspek elaborasi mendapat nilai rata-rata $54 \%$ dan meningkat menjadi $78 \%$.

Pada siklus I pertemuan pertama masih terdapat banyak kekurangan baik dari segi guru maupun dari masing-masing anak. Dari segi guru, guru kurang dalam mengontrol kelas sehingga pada saat guru mempraktekan pembuatan prakarya, banyak anak yang maju ke meja guru untuk melihat langsung media yang telah disiapkan guru, dan dari segi anak, masih terdapat beberapa anak yang tidak konsentrasi sehingga tidak menyelesaikan pekerjaannya. Permasalahan-permasalahn yang muncul dijadikan sebagai bahan refleksi bagi peneliti untuk pertemuanpertemuan selanjutnya.

Dilihat dari hasil individu masingmasing anak pada setiap siklusnya kreativitas seni rupa anak meningkat dengan baik. Pada Siklus I Pertemuan Pertama Terdapat 4 orang anak berada pada kriteria "baik" yaitu DAN, S, GPAR dan NTS. Terdapat 8 orang berdasarkan kriteria "cukup" yaitu AKO, HFS, HZS, HRAP, KA, KHF, MC, DAN AMH. Terdapat 5 orang pada kriteria "kurang" yaitu SP, RA, NAS, ZRK, MVAS. Terdapat 1 orang pada kriteria "sangat kurang" yaitu OA. Pada siklus I pertemuan kedua \%. Terdapat 5 orang anak berada pada kriteria "baik" yaitu HRAP, DAN, S, GPAR dan NTS. Terdapat 9 orang berdasarkan kriteria "cukup" yaitu AKO, RA, HFS, HZS, KA, NAS, KHF, MC, DAN AMH. Terdapat 4 orang pada kriteria "kurang" yaitu SP, OA, ZRK. Pada siklus I pertemuan ketiga Terdapat 7 orang anak berada pada kriteria "baik" yaitu AKO, HRAP, DAN, DA, S, GPAR dan NTS. Terdapat 10 orang berdasarkan kriteria "cukup" yaitu SP, RA, HFS, HZS, KA, NAS, KHF, MC, MVAS, DAN $\mathrm{AMH}$. Terdapat 1 orang pada kriteria "kurang" yaitu ZRK.

Pada siklus II peneliti masih menggunakan tahapan-tahapan kegiatan yang sama dengan siklus I tetapi pada setiap pertemuannya membuat prakarya yang berbeda. Pada siklus II pertemuan pertama peneliti membuat prakarya "Tempat Bunga", pada pertemuan kedua "karakter dari tutup botol" dan pertemuan ketiga "bunga dari koran".

Selanjutnya pada siklus II pertemuan pertama Terdapat 9 orang anak berada pada kriteria "baik" yaitu SP, AKO, HFS, HZS, HRAP, OA, GPAR, NTS, DAN AMH. Terdapat 7 orang berdasarkan kriteria "cukup" yaitu RA, KA, NAS, KHF, ZRK, MC, dan MVAS.. Terdapat 2 orang pada kriteria "sangat baik" yaitu DAN, dan S. Pada siklus II pertemuan kedua Terdapat 11 orang anak berada pada kriteria "baik" yaitu SP, AKO, RA, HFS, HZS, KA, OA, GPAR, NTS, MC, MVAS DAN AMH. Terdapat 3 orang berdasarkan kriteria "cukup" yaitu NAS, KHF, dan ZRK. Terdapat 3 orang pada kriteria "sangat baik" yaitu HRAP, DAN, dan S. Dan Pada siklus II pertemuan ketiga \%. Terdapat 12 orang anak berada pada kriteria "baik" yaitu $S P$, RA, HFS, HZS, KA, NAS, OA, HKF, MC, GPAR, MVAS, dan AMH. Terdapat 1 orang berdasarkan kriteria "cukup" yaitu ZRK. Terdapat 5 orang pada kriteria "sangat baik" yaitu AKO, HRAP, DAN, NTS dan S.

Pada siklus II pertemuan pertama kreativitas seni rupa sudah menunjukkan peningkatan dengan baik. Anak-anak semakin termotivasi dalam memanfaatkan bahan limbah anorganik yang ada disekitar menjadi sesuatu ynag menarik dan 
bermanfaat dengan membuat prakarya dalam kehidupan sehari-hari. Dan pada siklus II pertemuan kedua dan ketiga kreativitas seni rupa sudah mengalami peningkatan secara optimal baik dari aspek orisinal, resolution, dan elaborasi.

Dari uraian diatas dapat disimpulkan bahwa kegiatan membuat prakarya dengan media bahan limbah anorganik mendapatkan respon yang positif dari anak, Hal ini sesuai dengan pendapat Renzulli dalam Munandar (2000:25) kreativitas sebagai kemampuan umum untuk; (1) menciptakan sesuatu yang baru, (2) memberikan gagasan-gagasan baru, (3) pemecahan masalah, atau sebagai kemampuan untuk melihat (4) hubunganhubungan baru antara unsur-unsur yang sudah ada sebelumnya. Dilihat dari setiap hasil perolehan nilai rata-rata dan perolehan ketuntasan klasikal anak pada setiap pertemuan siklus I dan siklus II terdapat suatu peningkatan yang baik untuk anak. Berdasarkan uraian pembahasan diatas dapat disimpulkan bahwa membuat prakarya dengan bahan limbah anorganik dapat meningkatkan kreativitas seni rupa. Kegiatan membuat prakarya yang kreatif yang dikemas menggunakan media bahan limbah anorganik dapat memberikan pengalaman dan pemahaman kepada anak, sehingga aspek-aspek kreativitas seni rupa dapat ditingkatkan dengan baik. Maka dapat disimpulkan bahwa kegiatan prakarya dengan media bahan limbah anorganik dapat meningkatkan kreativitas seni rupa anak kelompok B1 PAUD Islam Intan Insani Kota Bengkulu. Hal ini terlihat dari meningkatnya presentase ketuntasan belajar secara keseluruhan dari 2 siklus yang dilakukan.

\section{KESIMPULAN}

Berdasarkan hasil penelitian dan pembahasan yang telah diuraikan pada bab sebelumnya, dapat disimpulkan bahwa:

1. Melalui kegiatan prakarya menggunakan media bahan limbah anorganik dapat meningkatkan kreativitas anak yang meliputi aspek orisinal, resolution, dan elaborasi. Perbedaan presentase dari siklus I ke siklus II peningkatannya dari $64 \%$ dengan kriteria cukup menjadi $84 \%$ dengan kriteria baik sekali

2. Melalui kegiatan prakarya menggunakan media bahan limbah anorganik dapat meningkatkan kreativitas seni rupa anak yaitu dalam aspek orisinal, resolution dan elaborasi. Hal ini terbukti pada ketuntasan anak secara klasikal yang telah mencapai ketuntasan sebesar 84\%, dan rata-rata kreativitas seni rupa anak pada aspek orisinal di siklus I sebesar 2,8 (cukup) meningkat menjadi 4,5 (baik) di siklus II, pada aspek resolution sebesar 3,1 (cukup) meningkat menjadi 4,2 (baik), pada aspek elaborasi sebesar 2,7 (cukup) menjadi 3,9 (baik) di siklus II. Dari hasil tersebut menunjukan bahwa kreativitas seni rupa anak mengalami peningkatan antar siklusnya.

\section{SARAN}

Berdasarkan hasil penelitian yang telah dilakukan, maka penulis memberikan saran yaitu:

1. Bagi Peneliti

Dari penelitian yang telah dilakukan diperoleh bahwa kretivitas seni rupa anak pada aspek orisinal, resolution, dan elaborasi berkembang secara optimal, maka peneliti lebih lanjut 
dapat melakukan penelitian tentang kreativitas seni rupa anak dengan kegiatan prakarya menggunakan media lainnya seperti media bahan alam.

2. Bagi guru/pendidik

Berdasarkan hasil penelitian diperoleh bahwa melalui kegiatan prakarya memberikan dampak positif terhadap peningkatan kreativitas seni rupa anak. Dengan demikian melalui kegiatan prakarya ini diharapkan dapat diterapkan oleh guru dalam mengembangkan potensi yang dimiliki oleh anak usia dini dan dapat mendukung dan bekerjasama dalam proses pembelajaran yang lebih bermakna bagi anak.

\section{DAFTAR PUSTAKA}

Barnawi, Dan Arifin Muhammad. 2014. Arikunto, Suharsimih. 2009. Penelitian Tindakan Kelas. Jakarta: Bumi Askara.

Sumanto. 2005. Pengembangan Kreativitas Seni Rupa Anak TK. Jakarta : Depdiknas Angkah Mudah Penelitian Tindakan Kelas Sebagai Pengembangan Profesi Guru. Jakarta: Raja Grafindo Persada.

Undang-undang RI No.20 Tahun 2003. Tentang sistem pendidikan nasional. Surabaya : Karina.

Waluyo, 2012. Makalah Kewirausahaan. (http://prakaryawirausahaan.blogspo t.co.id/2016/07/pengertianprakaryadan-kewirausahaan.html\#). Diunduh pada tanggal 7 Mei 2017. 